\title{
Data Envelopment Analysis for Malaysia Courier Services Performance and Customer Satisfaction
}

\author{
Teoh Yeong Kin ${ }^{1 *}$, Suzanawati Abu Hasan ${ }^{2}$, Siti Nur Atikah Zahari ${ }^{3}$ \\ ${ }^{1,2,3}$ Faculty of Computer and Mathematical Sciences, \\ Universiti Teknologi MARA, Perlis Branch, Arau Campus, 02600 Arau, Perlis, Malaysia \\ Corresponding author: *ykteoh@uitm.edu.my \\ Received Date: 16 August 2020 \\ Accepted Date: 15 October 2020
}

\begin{abstract}
One of the key issues of the current courier services in Malaysia is the efficiency of the courier itself. In today's competition, many factors have recognized that influence the efficiency of courier services. Hence, numbers of analytical models and formulas were introduced to measure the efficiency of courier service. This paper presents a practical approach for identifying the level of customers' satisfaction towards courier service companies using Data Envelopment Analysis and four courier services which were Poslaju, City-Link Express, J\&T Express, and GD Express in Hulu Terengganu were selected. Data Envelopment Analysis is chosen in this study because it can deal with complex connections between several inputs and outputs on performance evaluation issues. The input criteria considered in this study are assurance, empathy, reliability, responsiveness, tangibility, and price. Meanwhile, customer satisfaction is chosen as the output criteria. The results showed that Poslaju is ranked as the most efficient company, followed by City-Link Express in second and J\&T Express as the third. The least efficiency score obtained makes GD Express as the last ranked courier service among these four courier services. Furthermore, the results are mainly influenced by the input criteria of assurance, empathy, and tangibility. This study helps the customer to select the most efficient courier service that can save their time, money, and energy. Finally, this study also can guide courier services to decide on which criteria are effective to be improved to enhance their business performance.
\end{abstract}

Keywords: data envelopment analysis, courier services, customer satisfaction, criteria

\section{INTRODUCTION}

In many aspects, there is a rapid development of the courier services industry in Malaysia. In 2018, based on the Communications and Multimedia (C\&M) industry (2019), the industry contributed by $8 \%$ or RM 135.7 billion for Bursa Malaysia's overall market capitalisation of RM 1,700.37 billion. The postal and courier services like Pos Malaysia supported the C\&M industry by contributing turnover of RM 2.41 billion in 2018 but marginally decreasing compared to the 2017 turnover of RM 2.46 billion. Nevertheless, in the past five years, Pos Malaysia had stepped up due to its courier business, mainly in line with the growing e-commerce trend consisting of 119 courier service providers such as Poslaju, CityLink Express, J\&T Express, GD Express, SKYNET, and DHL

Customer satisfaction was vital as it offers a measure that could be used by marketers and business owners to control and strengthen their businesses. It is an essential element in the service industry as it leads to the loyalty of customers (Sze et al., 2012). Loyalty means that the consumer buys or retains a particular product model over a more extended period and takes a positive approach to business and its deals (Otsetova, 2017). Customers can be satisfied until a competitive service appears, the quality and price of which are more attractive. They can have positive attitudes toward a company but not be satisfied 
with the services and vice versa. This scenario demonstrates that the companies should take care of their customers properly since they are the source of revenue for themselves. Although the industry was springing up like mushrooms after rain, the courier services in Malaysia have to be competitive in this industry since the customers want the best out of their time, money, and efforts, while guidelines were available for achieving maximum customer satisfaction, the courier services still had trouble fulfilling it.

First and foremost, most courier services do not adequately conduct customer services such as being polite, responsive or showing respect. Somehow, human factors also influence the satisfaction of the customers (Chicu et al., 2019). Moreover, choosing a suitable courier service is essential and necessary. Delivery time is one of the most critical factors for choosing the courier for some people, such as online sellers (Nguyen et al., 2019). Nonetheless, some people, especially students, are worried about postage fees. Courier services who are not aware of this will result in being poorly rated if customers do not have expectations that match their payment.

A few numerical programming approaches have been utilized within the past. Vokurka et al. (1996) proposed integrating purchasing experts' decisions and expertise with ex-works' official approaches. They integrate a decision-support framework with expert system technology. Choy et al. (2002) to choose and benchmark suppliers by using the Case-Based Reasoning (CBR) and Neural Network (NN) techniques present an Intelligent Supplier Management Tool (ISMT). Choy et al. (2013) adapted the SERVQUAL model to measure customer satisfaction towards service quality and relate them to performance measurements. Ten key characteristic have been used in this model, which are reliability, responsiveness, competence, access, courtesy, communication, credibility, security, understanding the customer's need and tangibility.

Data Envelopment Analysis (DEA) which created by Charnes et al. (1978) as a generalization of the system of Farrell (1957) is an effective total comparative strategy for assessing the productivity of organizations with numerous inputs and outputs. Compared to the conventional framework of performance assessment, this method has several advantages. It gives a comprehensive index, permitting an objective assessment and comparison of workers, taking under consideration not as it were the outputs but to the inputs, and it can handle different inputs and outputs at the same time. Besides, DEA reacts to employees' desires to measure their inadequacies, overcome the disadvantages of quality assessment frameworks, and are not dependent on measurement units. Since this is a non-parametric approach, DEA isn't bound by the typical dispersion of input and output variables (Manoharan et al., 2009).

In this paper, DEA is used to analyse customer satisfaction towards courier services in conjunction with helping the courier service providers and their customers understand each other better and try to meet their demands on the price, effort and time spent. This paper aims to identify the customer's level of satisfaction towards the courier services, compare the efficiency of the courier services, and finally rank the courier service based on the performance.

The rest of this paper is organised as follows. The second section explains the methods used in this paper, followed by the third section that discusses the efficiency and performance among courier services. The fourth section presents the conclusions and future works.

\section{METHODOLOGY}

\section{Method of Data Collection}

In this study, customer satisfaction towards courier services became the focus of this study. Primary data were collected from four courier services located in Hulu Terengganu, which are Poslaju, City-Link Express, J\&T Express, and GD Express. Ten customers were chosen randomly from each courier service 
to answer the questionnaire. These respondents were qualified since they have been using these courier services in the last six months. The data focused on customer satisfaction towards assurance, empathy, reliability, responsiveness, tangibility, and price. The 5-point Likert scale was used to collect the data regarding the customers' satisfaction toward courier services with scores as such; $1=$ Strongly Disagree, 2 = Disagree, 3 = Moderately Extent, 4 = Agree, 5 = Strongly Agree.

\section{Method of Data Analysis}

DEA is a practical yet powerful method developed by Farrell (1957) and redeveloped by Charnes et al. (1978) for evaluating the efficiency of organizations using varied inputs and output. This method used in the suggested performance measurement system for evaluating several group entities known as Decision Making Units (DMUs). In this paper, four courier services which are Poslaju, City-Link Express, J\&T Express, and GD Express were referred as DMUs, while a linear programming model used by DEA to design a hypothetical composite unit according to the all units in the reference group. The proposed DEA formulation comprises of three stages as in Figure 1:

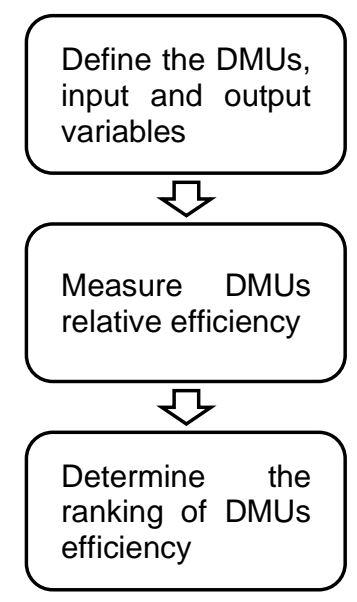

Figure 1: Data Envelopment Analysis Formulation

\section{Defining DMUs, Input and Output Variables}

Based on Figure 2 below, four courier services represented the DMU. Assurance, empathy, reliability, responsiveness, tangibility, and price of the courier services are utilized as the input factors to generate the data since they represent the level of the company's performance. The output for this research showed the efficiency of customers' satisfaction towards the courier services.

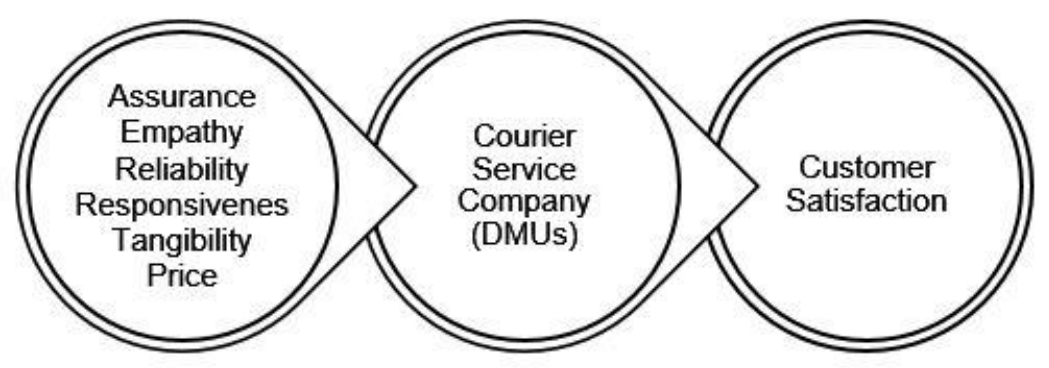

Figure 2: Flow of Input, Output and DMUs

\section{Measuring DMUs Relative Efficiency}

DEA Solver is used to generating the database collected from the 40 questionnaires distributed. In this paper, the Super Efficiency Slack Based Measurement (SBM) model was chosen. It allows direct consideration of the slacks in the model and resolving excess input and output shortfall. The Super 
Efficiency SBM model is designed based on SBM itself. Firstly, the data collected was tested using the SBM model to find the efficiency score. The effectiveness of DMUs determined by the highest ratio from the weighted sum of outputs to the weighted sum of inputs. Eq. (1) is used to calculate the efficiency of DMUs that can deliver the results regarding customer satisfaction towards courier services.

Minimize $R_{e}=\frac{\frac{1}{m} \sum_{i=1}^{m} \theta_{i}}{\frac{1}{s} \sum_{r=1}^{s} \varphi_{r}}$

where

$$
\begin{array}{ll}
\sum_{j=1}^{n} \lambda_{j} x_{i j} \leq \theta_{i} x_{i o} & i=1, \ldots, m \\
\sum_{j=1}^{n} \lambda_{j} y_{r j} \geq \varphi_{r} y_{\text {rio }} & r=1, \ldots, s \\
\theta_{i} \leq 1 & i=1, \ldots, m \\
\varphi_{r} \geq 1 & r=1, \ldots, s \\
\lambda_{j} \geq 0 & j=1, \ldots, n
\end{array}
$$

$R_{e}$ is the efficiency number, $\varphi_{i}$ is the efficiency measure for output $r, \theta_{i}$ is the efficiency measure for input $i, \lambda_{j}$ are reference weights associated with courier service $j, m$ is the number of input criteria, $s$ is the number of output criteria, $n$ is the number of courier service, $x_{i j}$ is the input criteria value for the $i_{\text {th }}$ criteria and the $j_{\text {th }}$ courier service and $y_{r i}$ is the output criteria value for the $r_{\text {th }}$ criteria and the $j_{\text {th }}$ courier service.

Through Eq. (1), four DMUs were assumed to exist and under consideration to convert into four outputs from six inputs. In particular, six inputs criteria which are assurance, empathy, reliability, responsiveness, tangibility, and price produced $y_{j m}$ outputs using $x_{i m}$ inputs. Under the DEA concept, the objective is to indicate the highest amount of outputs of DMUs that consume the least amount of input. Eq. (2) below is the formula after linear programming applied in the Eq. (1).

Minimize $\beta=\frac{1}{m} \sum_{i=1}^{m} \frac{t_{i}^{-}}{x_{i o}}$

where

$\beta+\frac{1}{s} \sum_{r=1}^{s} \frac{t_{r}^{+}}{y_{r o}}=1$

$\begin{array}{ll}\sum_{j=1}^{n} \mu_{j} x_{i j}=\beta x_{i o}-t_{i}^{-} & i=1, \ldots, m \\ \sum_{j=1}^{n} \mu_{j} y_{r j}=\beta y_{r o}+t_{r}^{+} & r=1, \ldots, s\end{array}$

$\sum_{j=1}^{n} \mu_{j}=\beta$ 
$\beta, \mu_{j}, t_{i}^{-}, t_{r}^{+} \geq 0, \quad j=1, \ldots, n, \quad i=1, \ldots, m, \quad r=1, \ldots, s$

The results of the DMU's efficiency score depends on the reference weighs. However, in DEA, it selects the weights that maximize the effectiveness of each DMU score, but in a condition that there is no negative weight, and the efficiency ratio should not be greater than one. The efficiency with the score below than one will not consider in the ranking DMUs Relative efficiency.

\section{Comparing and Ranking DMUs Relative Efficiency}

In this study, the results of the efficiency from the DEA solver that is not lower than one will be compared using the Microsoft Excel and was used to rank the efficiency of DMUs. Super Efficiency model is used and the formula as follows:

Minimize $\theta_{o}^{\prime}$

where

$\theta_{o}^{\prime} x_{i o}-\sum_{\substack{j=1 \\ j \neq 0}}^{n} x_{i j} \lambda_{j} \geq 0 \quad$ for all $i=1, \ldots, m$

$-\sum_{\substack{j=1 \\ j \neq 0}}^{n} y_{r j} \lambda_{j} \leq-y_{r o} \quad$ for all $\quad r=1, \ldots, s$

$\sum_{\substack{j=1 \\ j \neq 0}}^{n} \lambda_{j}=1$

$\lambda_{j} \geq 0 \quad j=1, \ldots, n$

$\theta_{o}^{\prime}$ Unconstrained but assumed positive

Where:

$\theta_{o}^{\prime}$ is the efficiency measure for employee $\mathrm{o}, \lambda_{j}$ are reference weights associated with employee $j, m$ is the number of input criteria, $n$ is the number of employees, $s$ is the number of output criteria, $x_{i j}$ is the input criteria value for the $i_{\text {th }}$ criteria and the $j_{\text {th }}$ employee and $y_{r j}$ is the output criteria value for the $r_{\text {th }}$ criteria and the $j_{\text {th }}$ employees.

Results obtained from ranking the DMUs showed the ranking of courier services for the customer's satisfaction. The courier that ranked first will be the most efficient services provider. In the meantime, the courier that ranked last is the least efficient services provider.

\section{RESULTS AND DISCUSSION}

\section{Data Collection from Questionnaire}

The result from this study pointed out the efficiency of courier services using the level of service quality provided by each courier services where assurance (A), empathy (E), reliability (R), responsiveness (Q), tangibility $(\mathrm{T})$, and price $(\mathrm{P})$. Customer satisfaction $(\mathrm{S})$ is the output of the six input criteria. Table 1 showed the results obtained from the average of Likert scale from six inputs and one output. 
Table 1: Data collected from the average Likert scale

\begin{tabular}{|c|c|c|c|c|c|c|c|}
\hline \multicolumn{7}{c}{ DMU } & \multicolumn{7}{c|}{ Criteria } \\
& A & E & R & Q & T & P & Output \\
\hline Poslaju & 3.75 & 3.45 & 2.90 & 3.03 & 3.63 & 4.40 & 3.78 \\
\hline City-Link Express & 3.73 & 3.50 & 3.40 & 4.25 & 3.67 & 2.30 & 3.70 \\
\hline J\&T Express & 4.15 & 3.80 & 3.90 & 3.98 & 3.73 & 2.97 & 3.96 \\
\hline GD Express & 3.20 & 2.48 & 2.93 & 3.28 & 2.87 & 2.37 & 3.06 \\
\hline
\end{tabular}

Table 2 explained the meaning of the scale from Table 1 in the qualitative measurement by converting the 5-point Likert scale into percentages.

Table 2: Customer satisfaction towards courier services

\begin{tabular}{|c|c|c|c|c|c|c|c|}
\hline DMU & $\mathbf{A}$ & $\mathbf{E}$ & $\mathbf{R}$ & $\mathbf{Q}$ & $\mathbf{T}$ & $\mathbf{P}$ & $\mathbf{S}$ \\
\hline Poslaju & $\begin{array}{c}\text { Moderate } \\
\text { Extent }\end{array}$ & $\begin{array}{c}\text { Moderate } \\
\text { Extent }\end{array}$ & Disagree & $\begin{array}{c}\text { Moderate } \\
\text { Extent }\end{array}$ & $\begin{array}{c}\text { Moderate } \\
\text { Extent }\end{array}$ & Agree & $\begin{array}{c}\text { Moderate } \\
\text { Extent }\end{array}$ \\
\hline $\begin{array}{c}\text { City-Link } \\
\text { Express }\end{array}$ & $\begin{array}{c}\text { Moderate } \\
\text { Extent }\end{array}$ & $\begin{array}{c}\text { Moderate } \\
\text { Extent }\end{array}$ & $\begin{array}{c}\text { Moderate } \\
\text { Extent }\end{array}$ & Agree & $\begin{array}{c}\text { Moderate } \\
\text { Extent }\end{array}$ & Disagree & $\begin{array}{c}\text { Moderate } \\
\text { Extent }\end{array}$ \\
\hline $\begin{array}{c}\text { J\&T } \\
\text { Express }\end{array}$ & Agree & $\begin{array}{c}\text { Moderate } \\
\text { Extent }\end{array}$ & $\begin{array}{c}\text { Moderate } \\
\text { Extent }\end{array}$ & $\begin{array}{c}\text { Moderate } \\
\text { Extent }\end{array}$ & $\begin{array}{c}\text { Moderate } \\
\text { Extent }\end{array}$ & Disagree & $\begin{array}{c}\text { Moderate } \\
\text { Extent }\end{array}$ \\
\hline $\begin{array}{c}\text { GD } \\
\text { Express }\end{array}$ & $\begin{array}{c}\text { Moderate } \\
\text { Extent }\end{array}$ & Disagree & Disagree & $\begin{array}{c}\text { Moderate } \\
\text { Extent }\end{array}$ & Disagree & Disagree & $\begin{array}{c}\text { Moderate } \\
\text { Extent }\end{array}$ \\
\hline
\end{tabular}

Table 2 showed that the customers moderately agree that they were satisfied with the J\&T Express services. However, the customers disagreed with the price offered by J\&T Express for using their services. Apart from that, there were two courier services that customers disagreed in terms of the price, which were City-Link Express and GD Express. As compared between these two courier services, CityLink Express is lower where the difference was only 0.07 .

Customers agreed that Poslaju offers the best price because they provide different packages with different price, and the price offered seems to be reasonable based on customers' perception. In terms of responsiveness, City-Link Express obtained the most significant scale. Customers agreed that City-Link Express provided better, high quality and timely service for its customers. Furthermore, customers moderately agreed with City-Link Express tangibility services. One of the factors that contributed to the results was because City-Link Express in Hulu Terengganu strategically located in the crowded community. Many customers prefer to go to the courier service that was nearby. Customers for GD Express mostly disagreed with the services provided such as empathy, reliability, tangibility, and price. Hence, these poor services had caused GD Express to receive the lowest scale in customer satisfaction.

\section{Efficiency of DMUs using SBM Model}

Results of the correlation between criteria obtained in Table 3 explained that a negative correlation between price and responsiveness caused a larger scale for the price to give out a lower scale for responsiveness. Besides, customers' satisfaction towards the courier is mostly affected by empathy since 0.9929 was the highest correlation. Courier services with flexible working hours and strategic location are 
also related to each other since these two criteria, empathy and tangibility had the second-highest correlation.

Table 3: Correlation between criteria

\begin{tabular}{|c|c|c|c|c|c|c|c|}
\hline & $\mathbf{A}$ & $\mathbf{E}$ & $\mathbf{R}$ & $\mathbf{Q}$ & $\mathbf{T}$ & $\mathbf{P}$ & $\mathbf{S}$ \\
\hline A & 1 & 0.9663 & 0.7978 & 0.4722 & 0.9089 & 0.3106 & 0.9664 \\
\hline $\mathbf{E}$ & & 1 & 0.6990 & 0.5015 & 0.9851 & 0.3421 & 0.9929 \\
\hline $\mathbf{R}$ & & & 1 & 0.7893 & 0.5868 & -0.2981 & 0.6451 \\
\hline $\mathbf{Q}$ & & & & 1 & 0.4657 & -0.6337 & 0.3969 \\
\hline $\mathbf{T}$ & & & & & 1 & 0.3892 & 0.9785 \\
\hline $\mathbf{P}$ & & & & & & 1 & 0.4458 \\
\hline $\mathbf{S}$ & & & & & & & 1 \\
\hline
\end{tabular}

Results in Table 4 from the SBM model indicates that all of the DMUs are efficient since all courier services' scores were 1 or 100 in percentage. Scores that were equivalent to 1 were considered as efficient and scored less than 1 and above 0 considered as inefficient. The number of efficient units identified by the SBM model, reaching the maximum efficiency score, $100 \%$ can be relatively high and especially in problems with the small number of decision making.

Table 4: Efficiency scores of DMUs

\begin{tabular}{|c|c|}
\hline Courier Service & Score \\
\hline $\mathbf{1}$ & 1 \\
\hline $\mathbf{2}$ & 1 \\
\hline $\mathbf{3}$ & 1 \\
\hline $\mathbf{4}$ & 1 \\
\hline
\end{tabular}

\section{Efficiency Scores and Ranking from Super Efficiency SBM Model}

This study used Super Efficiency SBM model, which allows the inputs and outputs to change nonproportionally. Results from Figure 3 depicted that all of the scores were higher than 1, and thus, this model helps in ranking DMUs. The rating position determined the performance ranking of the courier services. 


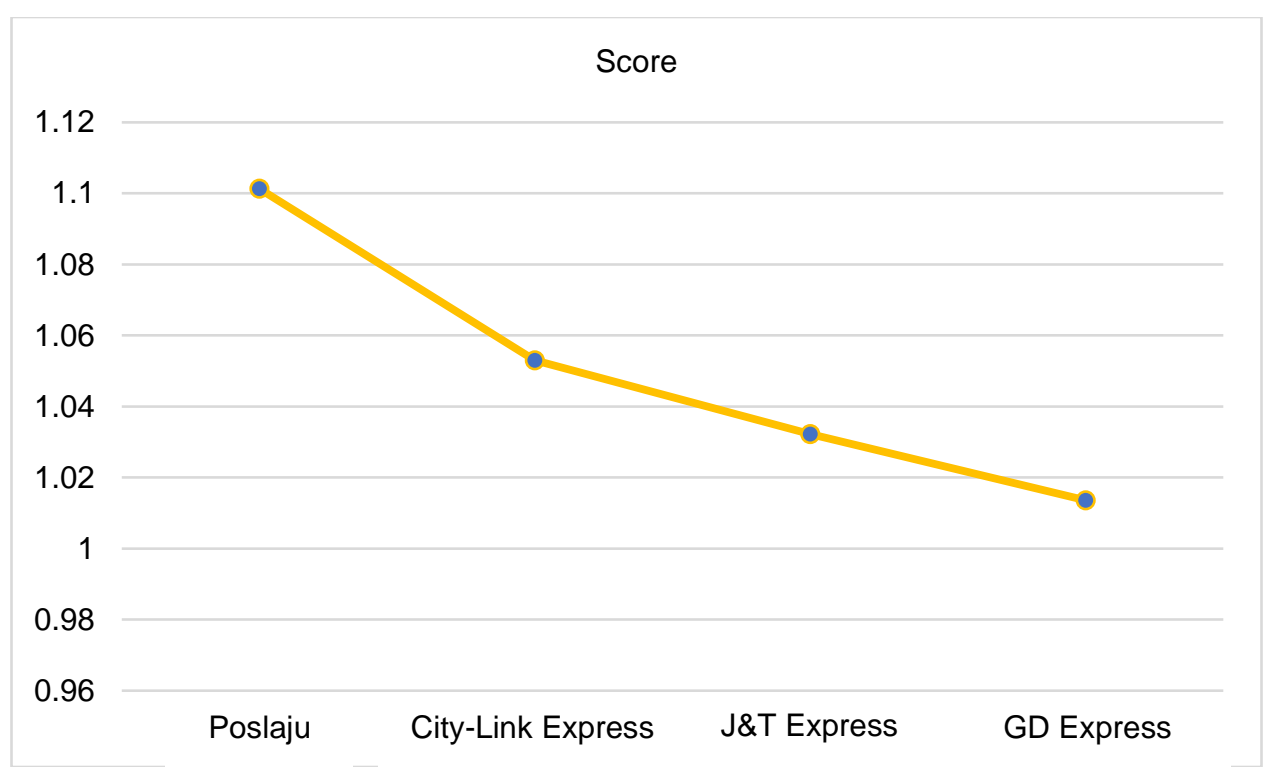

Figure 3: Scores of DMUs using Super Efficiency SBM model

It is clear that according to the proposed scatter plot in Figure 3, Poslaju is the most efficient courier service with the highest score of 1.10 and the lowest score that indicates the lowest ranking with differences 0.09 is the GD Express. City-Link Express is the second in ranking with 1.05 scores followed by J\&T Express with 1.03 .

Poslaju provides various services, such as paying bills and government services. Poslaju is also conjoined with dominant e-commerce such as Lazada and Shopee that increase their performance which makes it one of the reasons why customers rate highly on their services.

\section{CONCLUSION}

The main objective of this research is to identify the level of customers' satisfaction towards the courier services in Hulu Terengganu using Data Envelopment Analysis. The data is collected using the Likert scale for assurance, empathy, reliability, responsiveness, tangibility, price, and customer satisfaction towards the courier services. The paper presents results on the performance measurement model based on the ranking between Poslaju, City-Link Express, J\&T Express, and GD Express. This study is carried out based on ten customers from each courier services. This paper did not detect the relation between an efficient and inefficient unit since the result for all DMUs were efficient but rather outline ways to measure efficiency and to interpret the results of analyses. Based on the results, Poslaju ranked as the most efficient, followed by City-Link Express as the second and J\&T Express as the third. The least efficiency scored obtained by GD Express makes the last ranked. The correlation of the criteria also helps to figure out the weaknesses and strengths of the courier services. In conclusion, Data Envelopment Analysis assists the decision-makers to select the most suitable courier service for the villagers in Hulu Terengganu District. Besides, this study is significant to the courier services in order to overcome their weaknesses and improve their strength. 


\section{REFERENCES}

Charnes, A., Cooper, W. W., \& Rhodes, E. (1978). Measuring the efficiency of decision making units. European Journal of Operational Research, 2(6), 429-444. https://doi.org/10.1016/03772217(78)90138-8.

Chicu, D., Pàmies, M. del M., Ryan, G., \& Cross, C. (2019). Exploring the influence of the human factor on customer satisfaction in call centres. BRQ Business Research Quarterly, 22(2), 83-95. https://doi.org/10.1016/j.brq.2018.08.004.

Choy, M., Laik, M. N., \& Shung, K. P. (2013). Performance measurement design for a parcel delivery company. Lecture Notes in Engineering and Computer Science, 3 LNECS, 1565-1570.

Farrell, M. J. (1957). The Measurement of Productive Efficiency. Journal of the Royal Statistical Society. Series A (General), 120(3), 253. https://doi.org/10.2307/2343100.

Malaysian Communications And Multimedia Commission, (2019, August 21) Industry Performance Report. Retrieved from https://www.mcmc.gov.my/skmmgovmy/media/General/pdf/IndustryPerformance-Report 2018 compressed.pdf

Manoharan, T. R., Muralidharan, C., \& Deshmukh, S. G. (2009). Employee Performance Appraisal Using Data Envelopment Analysis: A Case Study. Research \& Practice in Human Resource Management, 17(1), 17-34.

http://search.ebscohost.com/login.aspx?direct=true \&db=bth\&AN=44922773\&site=ehost-live

Nguyen, D. H., de Leeuw, S., Dullaert, W., \& Foubert, B. P. J. (2019). What Is the Right Delivery Option for You? Consumer Preferences for Delivery Attributes in Online Retailing. Journal of Business Logistics, 40(4), 299-321. https://doi.org/10.1111/jbl.12210

Otsetova, A. (2017). Relationship between logistics service quality, customer satisfaction and loyalty in courier services industry. Management and Education, 13 (2). 51-57.

Sze, J., Ho, Y., Ong, D., Teik, L., Tiffany, F., Kok, L. F., \& Teh, T. Y. (2012). Logistic Service Quality among Courier Services in Malaysia. International Conference on Economics, Business Innovation, $38,113-117$. 